\title{
Technology, Listening and Historical Method: Placing Audio in the Postwar British Home
}

To be published in The Journal of the Royal Musical Association, autumn 2017.

Tom Perchard, Goldsmiths

\begin{abstract}
This article explores the ways that audio in the home was figured in (and helped shape) changing consumer and gender roles in postwar Britain. It looks at the ways that innovations in home furnishing and audio equipment design and manufacture created an environment with new tactile as well as sonic qualities; it examines the ways that changing music styles helped develop new markets for audio equipment, and new meanings for audio discourse. But before it does so, the article sets out some arguments on cultural-historical method. Extant academic writing on postwar home audio tends to privilege the study of media representation - and the critique of ideology constructed therein - at the expense of other kinds of enquiry and source work. In making use of a broader range of sources and interpretive approaches, this piece aims for a thick reading of the 'social' along with the 'cultural'.
\end{abstract}

Keywords: Audio, Home, Britain, Postwar, Technology, Historiography 


\section{Technology, Listening and Historical Method: Placing Audio in the Postwar British Home}

Millions of radiograms and gramophones sat in British homes by the beginning of the 1930s, functioning variously as the providers of gentle background music and talk, the focal points of concentrated listening, or the objects of inquisitive technical tinkering. Radio's indistinct valve-amp glow, the gramophone's boxy punch, the crackle and whoosh of both: for most listeners, that would do. But in the United States, soon after the second war, the collection of kit, thinking and modes of listening bundled up and branded by manufacturers and commentators as high fidelity - hi-fi - could be seen patching together kinds of audio experience, and kinds of prestige, not previously associated. This upmarket technology promised sonic clarity and presence way beyond that of commonplace equipment, the chance not to warm, or to puncture, but to truly fill domestic space with mediatised sound; the outlay necessary to procure it, the connoisseurship needed to justify it, brought a performance of musical taste that had usually been public in to a more private setting. Hi-fi's name, ideals and commercial discourses soon spread to Europe and beyond. More modest machines, too - radios, gramophones and stereograms - were less privileged but increasingly popular fixtures.

To historians of music, such equipment has usually seemed distinct from (and distinctly less significant than) the sound it transcribed, even when that music could only have been heard mechanically. But studies of postwar audio, often made by scholars outside music studies per se, are growing in number. This work might be sorted into three categories. The first type, and the longest-established, narrates the twin development of audio systems and musical culture, and, though work here considers the changing social meanings as well as the scientific details of sound technology, the domestic scene tends to feature less than the research laboratory or recording studio. ${ }^{1}$ Following are focused histories of specific sound media - radio, the spoken word record - though again these can tend to concentrate on the agents of production before the living rooms to which their material was disseminated. ${ }^{2}$ The third category, and the one most relevant to the present study, is also the newest: this

\footnotetext{
${ }^{1}$ Walter L. Welch and Leah Brodbeck Stenzel Burt, From Tinfoil to Stereo: The Acoustic Years of the Recording Industry, 1877-1929, revised edition (Gainsville, 2006); Greg Milner, Perfecting Sound Forever: An Aural History of Recorded Music (London, 2009); Mark Katz, Capturing Sound: How Technology has Changed Music, revised edition (Berkeley, 2010).

${ }^{2}$ This is especially true in Britain, where studies of radio or television can be dominated by the British Broadcasting Corporation and its institutional machinations. A notable exception is Simon Frith, 'The Pleasures of the Hearth', Formations of Pleasure, ed. Tony Bennett et al (London, 1983), 101-123; Susan J. Douglas' Listening In: Radio and the American Imagination (New York, 1999) also considers the domestic at length. A history of American spoken word recordings (often focused on record labels) is provided in Jacob Smith, Spoken Word: Postwar American Phonograph Cultures (Berkeley, 2011).
} 
comprises histories of home audio and listening which, often using the specialist press as their evidence base, attempt to show how cultural values of all kinds were constructed through the sound media and practice. ${ }^{3}$

An early and influential outlining of the latter category was made by Keir Keightley in his 1996 essay on hi-fi, gender and domestic space. ${ }^{4}$ Reading American magazines like High Fidelity and Hi-Fi and Music Review, Keightley argues that the 1950s production of hi-fi - in the material and the abstract, its instruments and ideas - transformed audio equipment into a specifically masculinist technology. New trends in the spatial and social organisation of American family life, most obvious in the new suburban developments that removed families from the dense multiplicity of the city and set them in static, open-plan contact, meant that men were spending more time at home, and in homes that sometimes allowed them less private space than had been the case. So a hi-fi hobby could be an assertion of power, since, to believe the magazines, those men who installed hi-fi at home enjoyed the Chicago Symphony's brass section fizz, or a demonstration disc's passing locomotive roar, for its 'real' presence, dynamic range and volume above all else. That meant trouble: as Keightley demonstrates, the literature was full of features both serious and satirical on the domestic strife that this assertive, territorial noisiness inspired. Whereas 1960 s arguments over music's loudness were figured as conflicts between generations, Keightley writes, in the 1950 os those arguments were described as taking place between men and women, or rather husbands and wives.

Keightley's hi-fi study draws only on American sources. Perhaps that's understandable, given the country's centrality in both the invention and early consumer take-up of the equipment described - and anyway, national differences in

\footnotetext{
3 Examples are Tim. J. Anderson, Making Easy Listening: Material Culture and Postwar American Recording (Minneapolis, 2006); Thomas Everrett, 'Ears Wide Shut: Headphones and Moral Design' (Ph.D. dissertation, Carleton University, 2014); Kyle Devine, 'A Mysterious Music in the Air: Cultural Origins of the Loudspeaker', Popular Music History, 8/1 (2014), 5-28; Living Stereo: Histories and Cultures of Multichannel Sound, ed. Paul Théberge, Kyle Devine and Tom Everrett (New York and London, 2015). In addition, there is an ever-growing literature on music and listening in everyday life that emanates from a sociological perspective, and which is concerned with lived space, listening, and identity construction. These issues are in play here. But while this work is often useful, much of it is well-known enough not to be rehearsed again, especially since it is not primarily (or even at all) concerned with historical experience and interpretation. See Tia DeNora, Music in Everyday Life (Cambridge, 200o); Anahid Kassabian, Ubiquitous Listening: Affect, Attention, and Distributed Subjectivity (Berkeley, 2013); Antoine Hennion, 'Music Lovers: Taste as Performance', Theory, Culture, Society, 18/5 (2001), 1-22; Georgina Born, 'Listening, Mediation, Event: Anthropological and Sociological Perspectives', Journal of the Royal Musical Association, 135, supplement 1 (2010), 79-89, and 'Music and the Materialization of Identities', Journal of Material Culture, 16/4 (2011), 376-388. A small amount of work with a contemporary focus addresses hi-fi culture: Marc Perlman, 'Golden Ears and Meter Readers: The Contest for Epistemic Authority in Audiophilia', Social Studies of Science, 34/5 (2004), 783-807; Sara Jansson, “Listen to these Speakers”: Swedish Hi-Fi Enthusiasts, Gender, and Listening', Journal of the International Association for Popular Music, 1/2 (2010) doi:10.5429/20793871(2010)vii2.5en.

4 Keir Keightley, “'Turn It down!” She Shrieked: Gender, Domestic Space, and High Fidelity, 1948-59', Popular Music, 15/2 (1996), 149-77.
} 
discourse and practice sometimes seem to have been minimal. A 2009 study by Alf Björnberg that takes mid-century Swedish consumer magazines as its principal materials - this piece all but alone in its extended treatment of a historical hi-fi discourse outside the United States - does not reveal a culture qualitatively different from the American model. Mobilising ideas suggested by Keightley along with influential theoretical work by Jonathan Sterne, the writer surveys three decades of specialist journalism in which product commentary and excited audio idealism seem indistinguishable, new products always must-have breakthroughs, and yet 'true' fidelity always just over the horizon. 5

The resonances between these national cultures may in part arise from Björnberg's synthesis of approaches taken in the field's dominant studies. And before looking at audio in the British home in any detail, it's important to think about the methods used to access historical experience and meaning: it's my contention that academic explorations of music reproduction technology emerging since the $1990 \mathrm{~s}$ can be useful not just for what conclusions they reach, but for what they say about common - but underexamined - cultural-historical methods. Such methods, I'll argue, tend to overlook the differences between those attitudes towards audio constructed in public, written discourse, and those developed amid a more routine (and private) lived experience; they tend to focus on certain types of specialist, historical source and activity because those things enable certain types of contemporary theorisation - but, in so doing, they often overlook practices that were less often critically staged while being more widespread. These kinds of problems are not limited to work on audio or technology, having been signalled in much wider debates around contemporary cultural history writing. And whatever the objections I raise, the texts I discuss remain highly valuable for those wanting to build on them. ${ }^{6}$ My aims, then, are twofold. The first is to provide a critical historiography that might sharpen the focus of the second, which is to provide a new understanding of audio in the postwar British home: its changing status in a developing consumer culture, its varying roles in everyday listening lives.

\footnotetext{
5 Alf Björnberg, 'Learning to Listen in Perfect Sound: Hi-Fi Culture and Changes in Modes of Listening, 1950-80', The Ashgate Research Companion to Popular Musicology, ed. Derek B. Scott (Farnham, 2009), 105-129. Jonathan Sterne's book, The Audible Past: Cultural Origins of Sound Reproduction (Durham, 2003) has been important for those studying historical audio technology. Taking his methodological cues from Science and Technology Studies, and in particular the Actor-Network Theory identified with Bruno Latour, Sterne uses inventors' reports, journalists' commentaries, adverts and technical manuals to track the creation not just of instruments themselves - telegraph, telephone, radio, gramophone - but of a multiply negotiated 'audile technique'; these learned and taught techniques of listening, speaking and thinking disciplined unruly technologies until their latterly-standard functions took root, the phonograph becoming a machine for music rather than business dictation, the radio becoming a tool for broadcast rather than point-to-point communication.

${ }^{6}$ See for instance Peter Mandler, 'The Problem with Cultural History', Cultural and Social History, 1/1 (2004), 94-117, and the numerous replies across subsequent issues of the same journal.
} 
Keightley opens his piece by recounting a satirical vignette from a 1954 issue of High Fidelity, in which a hi-fi enthusiast, besieged at home by the noise of his children and by his wife's admonishments to keep it down, designs a man-sized box to sit in alone, his only portal to the outside world a slot through which his partner can pass sandwiches. To write $20^{\text {th }}$-century cultural history in the postmodern 1990 s often meant looking back at popular discourses through the squint of suspicion, and the unremarkable or throwaway was often read for what was said, sometimes without saying, about faultlines that would soon cleave wide open, for complacent claims of progress or superiority that would turn out hollow. So a critical reading of that comic article, such as Keightley provides, has to look beyond the joke to see the performance of gender role and willed autonomy already described: the piece's author, Keightley writes, 'imagines high-fidelity technology as a means of simultaneously transforming and escaping domestic space', and the article is thus 'representative of the gendered values of high fidelity during the 1950s'.7 But it was a joke, and one that worked not because masculinity was shown as a power able to transform and escape - in fact, precisely the opposite. Gags like this were common, showing that this was a subcultural discourse rather more ambivalent about itself than contemporary critical summaries might suggest; any historical conclusions drawn need to be equally open to ambiguity.

One of the challenges for the historian is to consider not just a discourse's textual products, but also the practical ways those texts were produced - and not just produced, but also received and answered. Journalistic copy has often been written to fill the maximum space in the minimum time, and the pieces that Keightley cites, male- and female-authored, can sometimes constitute little more than a restatement of the rules of the game ('hi-fi is a masculine activity'). Journeyman articles written according to the same code appear in the British press across the 1950s and 60s. But it's a somewhat thin reading that imagines all of these statements to be sincerely made and sincerely understood, and a focus on historical media discourse - or rather, on professional, written commentary - makes it difficult to perceive how writers and readers might have lived by different rules amid generic discourses than

\footnotetext{
7 Keightley, ‘Turn it Down', 149-50. Marie Thompson has provided a further, highly suggestive theorisation of this historical trope: Thompson argues that, in the mid-century hi-fi imaginary, the wife, supposedly unable to listen without gossiping, was being figured as metaphorical as well as literal 'noise' in relation to hi-fi's pure (masculine) signal. Marie Thompson, 'Gossips, Sirens, Hi-Fi Wives: Feminizing the Threat of Noise', Resonances: Noise and Contemporary Music, ed. Michael Goddard, Benjamin Halligan and Nicola Spelman (London, 2013).
} 
they did off paper. If, for a moment, one turns the hermeneutics of suspicion prevalent in earlier cultural history towards suspicious cultural history itself, there is a suggestion that behind these 2-d 'representations' lingers a more complex set of relationships being lived in fluid motion, aspects of which should be within history's grasp.

Here's an example of how convincing cultural-historical interpretations can start to unravel when different voices intervene. Advertisement representations of the lone male home listener were remarkably widespread and stable across time: from the 1950 s through to the 1970s, men were endlessly pictured in an armchair facing the speaker - after the introduction of stereo, between the speakers - attentive and thoughtful as they immersed themselves in the Pastoral Symphony, or else tested for treble roll-off with a copy of My Fair Lady. In his contribution to the volume Living Stereo: Histories and Cultures of Multichannel Sound (2015), Tony Grajeda writes about these illustrations of men listening from the 'sweet spot', that place in the room where the stereo image was perfectly calibrated and those armchairs were supposed to be positioned; following the established cultural-historical critique of hi-fi's gendered potential, Grajeda fingers this advertising trope as another patriarchal assertion of 'mastery, control and the fetishisation of technology' in the postwar home, a powerplay in which withdrawn and all-observing $20^{\text {th }}$-century Man engages in a kind of domestic sublime.

Through both channels and in both ears, the discourse and the apparatus converge, together seeking to situate a listener in what has been billed as the sweetest of all possible spots: a single point from which a listening subject gathers in a world of sound, and for whom alone it is believed that world of sound exists. ${ }^{8}$

It's a decent description of the images in question, and of the aggrandising tribute that advertisers and writers offered the customer king in the US as in Britain. Yet, very occasionally, female commentators on hi-fi were able to give public accounts of the private sphere, and these could show that this system of representations had different registers, and that this cipher of masculine connoisseurship and consumerism was exchangeable for its jokey twin. Responding in 1969 to a piece of sexist drollery in a recent issue of the British Hi-Fi News - this one of many threadbare satires on chatterbox women and their supposed inability to listen with audiophile focus - Mrs. P. Sindall of Burgess Hill wrote that, in fact:

\footnotetext{
8 Tony Grajeda, 'The "Sweet Spot”: The Technology of Stereo and the Field of Auditorship', Living
} Stereo, 40, 60. 
[n]ot many people can sit and do nothing for long. If my husband decides to do an hour's listening, he spends five minutes with eyes shut and ears glued, and the other fifty-five minutes jumping up and down adjusting bass, treble, and volume controls, exchanging a well-loved record for a test record, and assuming all sorts of weird poses all over the carpet ... Having bought several records myself, I long to be able to spend a quiet evening on my own, actually hearing a complete piece of music from start to finish, without my husband's interference. 9

If it was an objection, it was made according to a shared, comic, discursive protocol. But other types of sources show - as if we couldn't imagine - that the stereo sweet spot was not always occupied by self-possessed masculine figures or even their satirical double. A change of register, from the highly abstract to the truly quotidian: P.H., a clerical worker from Caterham, was a sporadic diarist. She was plagued by chronic ill health, and in 1964, nearing 40, she lived with her parents, themselves not infrequently ill. With few friends to speak of, P.H. passed most of her free time with books, music and TV; as she reported in her diary, she listened attentively and with discernment to the music, but also to what she sometimes referred to as its 'reproduction', engaging with the stereo medium at a time when, in the UK, mono still predominated. ${ }^{10}$

Monday 2 March 1964: Pleased to get one or two new records - mummy collected today the record I ordered Saturday - 'The White Heather Club' in stereo. This is an extremely pleasant record with a lot of spirited music and a very friendly atmosphere. Am disappointed Duncan MacRae was not doing 'The Sparrow', but am very pleased with it all the same.

Thursday 23 April 1964: Received records from the Concert Club - excerpts from 'Die Fledermaus' sung in German - was a little disappointed in it at first, because the tone didn't sound quite right, but later this seemed to wear off and I enjoyed the record very much indeed. It is gloriously vivacious. Played it through twice and enjoyed singing to it in German. In to front-room to watch 'This is Your Life' - Olivia de Havilland - and the news.

Saturday 25 July 1964: On return played Canasta, Beat your Neighbour. New records arrived today ... 'Sweethearts on Parade', 'Drums \& Pipes of the Highlands' - a very good record full of skirling bagpipes - and 'Le Pompom Rouge', the band of the French marines playing a number of French marches. Very enjoyable (this is in stereo) but the tone of the record is higher than I quite like. It may improve later on as they sometimes do. ${ }^{11}$

\footnotetext{
9 'Our Readers Write', Hi-Fi News, 14/5 (May 1969), 603.

${ }^{10}$ In the same year, PH's household was one of the first to trial a colour TV ('a bit of a letdown').

${ }^{11}$ Diary of P.H., The Great Diary Project, Bishopsgate Institute Library, file GDP 133/1964.
} 
P.H.'s use of the mail-order Concert Club, one of several record clubs designed above all for neophyte collectors, might have attracted the disdain of some hi-fi buffs. ${ }^{12}$ Yet the music she was buying closely matched the repertoire covered in those buffs' specialist magazines, and - apart from being recorded in private rather than public the critical language she used to describe music and media differed little from that found in Hi-Fi News' record reviews. Still, her relationship to that constructedly serious, powerful, masculine home listener Grajeda describes could not have been more tenuous.

I don't contrast these accounts to argue that the smallest scrap of dissenting empirical evidence can automatically invalidate broad theoretical suggestion. Historical investigations need to be conducted on both levels, and without necessarily seeking simple accordance between the two. Nor do I suggest that the study of media representations should be done away with - indeed, later parts of this essay will make use of what is still a vital method. The problem I see here is that the complexity of socio-historical experience is not signalled; despite its critical stance, Grajeda's reading ends up taking a media discourse given to hyperbole at face value, and the overheated, somewhat judgemental interpretation he is obliged to offer is not uncommon. ${ }^{13}$ Too often, cultural histories of this kind seem overly keen to chide the marketeers and consumers of the past; those people, touting or buying into progressivist narratives of material or interior comfort, are presented not just as the shills and dupes of earlier consumer culture, but even - it is sometimes implied - the dutiful footsoldiers of a more sinister force, Western techno-capitalism, its professed rational superiority masking a primitive chauvinism, rapaciousness and vulnerability that would be exposed by later generations. The historical gaze that only locates naive or reactionary views of the past, picturing traces, gestures and practices as epoch- or epistemology-defining truths, is one that needs checking.

In this essay, then, I will try to pick a new route through the history of audio in the 1950 and 6os home. A basic aim will be to situate the study in a new region - Britain - so as to cross-check Keightley's conclusions in a related context, and to begin to ask how far hi-fi and audio cultures varied within what was a transnational phenomenon. But a slight difference of methodological emphasis will, hopefully, locate more

\footnotetext{
12 In Britain the growing popularity of stereo records among record club listeners was noted as representing the expansion of a mid-range audio market. Economic Intelligence Unit, 'Special Report No. 2: Gramophone Records', Retail Business 98 (April 1966), 26.

${ }_{13}$ Several other essays in the same volume are more concerned with the philosophical critique of notions of fidelity and 'realness' rather than the domestic setting in which much experience of stereo audio was played out, or indeed the possibility of social and geographical variation between listening cultures and discourses.
} 
complexity of meaning, more multiple experience of home audio than is allowed by sometimes-reductive studies of media representation, and of the voices privileged therein. Making more use of economic data, I want to materially recast what risk becoming presentist, theoretical arguments, and that means considering audio as one domestic technology among many; it means using different kinds of sources and information - those that can give us either wider or much narrower perspectives on home life than readings of magazine editorial alone can manage - but it also means using similar sources in a slightly different way. If the words of the magazine discourses give a masculinist, elite point of view, then perhaps the images - and the adverts - can be read as speaking to readers otherwise; if those sources don't tell us much about home consumerism in a broader sense, then trade reports will, and if they don't often allow different voices to be heard, then diaries and other papers do. Underpinning the project is an attempt to understand hi-fi and home audio as an often new kind of experience - an experience of modernity - and, without renouncing criticality, to try to touch and feel that newness rather than to offer one more comment on its ideological delusions.

The most basic change of approach here is to extend the study of audio beyond niche hi-fi culture, opening up the investigation to include the experience of different technologies, classes and age groups. But I'll be the first to note that walls remain in place, most notably in terms of ethnic-cultural difference. In Britain, the volume of domestic recorded music came to form a key trope in debates around mass immigration in the 1950 s and 6os, with West Indian audio culture in particular often charged with straining boundaries between public and private, or else with bearing the weight of collective identity and memory; if those uses of audio do not appear here, it's because they need their own full-length study. ${ }^{14}$ Nor does that broader focus mean that hi-fi will receive short shrift. Indeed, since that kind of technology was assessed in such detail, and since it has accounted for almost all academic study of domestic music reproduction up to now, it's as well to begin there.

\section{Hi-fi and the modern British home}

A simple narrative of hi-fi's development over the 1950 s and 6os goes like this: at its emergence - the term became widely used, and attached to expensive and highquality instruments, from the early 50s - hi-fi was a hobbyist's pastime, and equipment that looked much like those instruments its enthusiasts would have used

14 See, as one example among many, the angry exchange of letters on this subject between M. Blundell of London N22 and T.C. Walster of Dartford in The Listener 5 January 1961, 34 and 12 January 1961, 75. 
in the field at Monte Cassino or Okinawa came almost uncased, wired together at home with little concern for look. ${ }^{15}$ But over the 1950s, hi-fi manufacturers seeking a mass market began to present boxed units that, with wires hidden and fascia discreet, could sit quietly in a living room until called upon. By the end of the 1960 s the transformation was complete, and something like hi-fidelity audio was a fixture of many homes (if still concentrated in the affluent classes).

Hi-fi's story is thus the story of modern consumerism, and an experience of both musical and industrial modernity that found its meaning precisely through its massproduced, mass-market nature. That accounted for all kinds of trends in household design and organisation then ongoing. But hi-fi was not simply invented and plugged in to an existing domestic setting: rather, in its development and uptake, it played a part in the aesthetic, sensual and economic transformation of the postwar home. Those transformations are the subject here.

To the British of the 1950s, domestic 'modernity' was not an abstract thing. A third of houses had been destroyed or damaged during the war, and an unparalleled reconstruction effort in social and private housing, often heady with socialdemocratic idealism, continued through the 1950s and 6os. In the rhetoric and literature of urban planning, building and renovation, the word 'modern' was applied with uniform optimism. In new developments the trend was not so much towards increasing the number of rooms - and thus opportunities for audio privacy and sound insulation - as it was towards increasing room size. Limited plot sizes inspired an increasing use of open plan layouts so as to maximise the experience of space and light, and architect-led construction initiatives working to realise these new environments, like those of the Span practice, were mimicked by the many speculative builders whose imitative estates soon dotted the country. Features on the 'modernisation' of tired or bomb-damaged Victorian and Edwardian buildings were a staple of magazines like Ideal Home, and the projects pictured usually entailed the knocking through of small ground floor rooms to create single, larger spaces; postwar government directives ensured even greater internal volumes for social housing than was common in private developments. ${ }^{16}$ New utilities joined. Light and heat, spareness and space, the gadgets to keep everything clean: this was the modern, at least in theory.

Some of the figures in that space represented a kind of design modernity that had already taken root in homes across the class and taste spectrum, if only because it had been imposed: in wartime, furniture had been manufactured to government-

15 Sterne shows this trend at work in an earlier generation's use of radio. Sterne, The Audible Past, 203. ${ }^{16}$ Graham Towers, At Home in the City: An Introduction to Urban Housing Design (Amsterdam, 2005), $39 \mathrm{ff}$. 
approved 'Utility' models, these Scandinavian-styled and lean to save manufacturing time and materials. Despite much objection to its lack of cosiness, what was called the 'contemporary' furniture style endured after 1945, standing in contrast to - and often in the same room as - the heavy, dark and decorative reproduction styles that had been in favour for decades. ${ }^{17}$ That old styling was often given to the bulky radiograms that commonly buttressed a sitting-room wall, and which, like the $19^{\text {th }}$ century parlour piano, could function as furniture as much as sound source. Sound, indeed, was usually indifferent, and the radiogram - utilitarian if not incommunicado - was viewed with suspicion by hi-fi enthusiasts. As Keightley remarks, hi-fi's unruly early appearance set up a contrast between 'seriousness' and looks, the specialist and the popular. ${ }^{18}$

Yet if these new audio systems were to make an appearance in shared domestic spaces, they would have to be hidden somehow. Concealing sideboards, chests and coffee tables with sliding tops were very often homemade, though a number of advertisers offered cabinet making services through the latter-1950s and early 1960 . To a limited extent, they were also offered as readymades - Heal \& Son were early to market - and with the 'Scandinavian' being the prime signifier of the modern project, that already familiar language of design economy played a leading role. Unadorned teak units floating on splayed legs abounded: from 1958 the Record Housing Co. advertised its 'Nordyk' cabinet, Howland-West following a few years later with its own 'Karelia de Luxe' and 'Malmo' models. ${ }^{19}$

The mix of handmade, semi-custom and limited mass-production methods used in furniture manufacture at the start of the 1950s was the same as that seen in audio production, so early hi-fi was not a home-constructed feature out of place in a massproduced culture: before the globalised and Common Market, imported equipment was comparatively rare and expensive, and a good proportion of British kit would come to be made by the dozens of small audio firms springing up - in light industrial units along the back streets of suburbs like Catford and Holloway - through that decade. ${ }^{20}$ But ways of making and buying household goods were changing across the

\footnotetext{
${ }^{17}$ Claire Langhamer, 'The Meanings of Home in Postwar Britain', Journal of Contemporary History 40/2 (2005), 347.

18 Keightley, 'Turn it Down', 162. Kyle Barnett shows how, in the USA of the early-29 ${ }^{\text {th }}$ century, phonographs and concealing furniture converged not just in the living room, but also in the factories of the firms that had begun to produce both kinds of item. Building on Holly Kruse's work, he shows how 'home' was, at this place and point in time, conceived of as a sanctuary free from mass culture and media. Something similar had been true in Britain, although as I will continue to show, that was changing in the 1950 os and 6os. Kyle Barnett, 'Furniture Music: The Phonograph as Furniture, 19001930', Journal of Popular Music Studies, 18/3 (2006), 301-324.

${ }_{19} \mathrm{Hi}$-Fi News, 2/10 (March 1958), 574. Hi-Fi News, 11/2 (July 1966), 123. Bang \& Olufsen and Tandberg adverts of the 1960 s made much of the companies' Scandinavian design nous.

${ }^{20}$ Judy Attfield, “'Give 'em Something Dark and Heavy”: The Role of Design in the Material Culture of Popular British Furniture, 1939-1965', Journal of Design History, 9/3 (1996), 195-196.
} 
board. The identity of a furniture producer had been of lesser importance to buyers than that of the retailer, and it was only when a few companies began to develop coherent house styles around standardised mass-produced ranges that manufacturers seized the industry balance of power. E. Gomme's G-Plan series, launched in 1953, was soon the most famous and powerful among them. At a time when manufacturers of reproduction furniture would add small, hand-crafted details to bulk-produced units - fig leaves both literal and metaphorical - ranges like G-Plan or Stag's Modern C flaunted their machine-tooled modernity, becoming synonymous with a certain kind of aspiration, status and self-image. They also signalled a new form of consumption, since, buyable piece-by-piece rather than in traditional combinations like the three piece suite, they enabled smaller, staggered and more personalised purchases. It's symbolic that G-Plan also advertised a range of hi-fi cabinets from 1958; that company's branding, modularity and replacement of craftwith mass-production was increasingly to be seen in the hi-fi field from around that time. ${ }^{21}$

Also synchronising were public interests in home design and home media. At first, the taste for modern design was part of a wider system and sense of cultural capital that could be organised and constrained along class lines. At a 1953 London exhibition staged by the Design Industries Association, a modern sitting room was staged next to a traditional set-up. Interviewed there, an anonymous typist in her early twenties said of the modern:

Wonderful tones of colour are picked up all around the room. But I would never live it in. For one thing, my family would have a fit, they'd think I'd gone quite mad and all arty. You see, I'd have to be a different person, I'd have to read the best books and listen to the Third Programme, don't you agree?22

By dint of its technological ambition, hi-fi too was a modern household project; by dint of its expense and cultural associations - not least with the classical music evoked here in the mention of the BBC's highbrow radio station - it was one that belonged largely to the professional classes. Home and hi-fi magazines shaped and pictured the same modern bourgeois imaginary, with Hollywood another key broker: along with the Scandinavian, the image of domestic modernity - mostly unattainable

\footnotetext{
${ }^{21}$ Early examples of this branded modularity, though not then widely available in Britain, could be seen in the Braun products designed by Dieter Rams' team in West Germany. Klaus Klemp, 'Dieter Rams: Early Works', Less and More: The Design Ethos of Dieter Rams, ed. Keiko Ueki-Polet and Klaus Klemp, (Berlin, 2011), 335.

${ }^{22}$ Christine Lalumia, 'At Home with Modern Design 1958-1965: A Case Study', British Design: Tradition and Modernity After 1948, ed. Christopher Breward, Fiona Fisher and Ghislaine Wood (London and New York, 2015), 74.
} 
to the British, apart from a new fireplace or section of wood panelling - was defined by the American modern house after Frank Lloyd Wright, with its celebration of stone, brick, wood, glass and volume. Hi-Fi News' cover feature of June 1960, 'Hi-Fi in America', pictured and verbalised the writer's awe at the space and style on offer Stateside, and the audio-equipped open plan on show in that piece was replicated in many of the magazine's spreads: 'Mr Farr, in common with many readers', ran one photo feature on readers' installations, 'appears to combine an interest in audio with a fondness of architecture and interior decoration, and white-painted brick walls ... are very well matched by the surrounding furniture and lighting'. ${ }^{23}$ A contents-page note on the cover illustration of the journal's December 1968 issue - brick walls, pendant lighting, Eames chair, Armstrong hi-fi units - asked readers not to write in, complaining that the last such picture set-up had excited more queries about the furniture than the audio equipment.

Eames and Armstrong were not household fixtures, but they occupied the top end of a modern design market that had by that time expanded to include all classes of consumer and budget. The anonymous typist's qualms had soon subsided - by the end of the 1950s, mass-produced contemporary furniture styles had grown to account for around half of all furniture purchases - and by the middle of the following decade, the field of the contemporary could be seen to encompass the relatively exclusive designs of a Robin Day, the innovative branding of Terence Conran's Habitat, and G-Plan's High Wycombe low modernism. ${ }^{24}$ As we'll see in more detail, home audio markets developed in similar ways at the same time, and, in both areas, popularising ranges and strategies were criticised from 'above' for their debasing of innovative design. ${ }^{25}$

Yet production-line (and superstore) modernity was ever-more firmly established; the British were learning new roles in economic agency, and learning how to reproduce them. The discerning consumer's magazine Which? was established in 1957, and 'admag' television programmes like Jim's Inn (ITV, 1957-63) strung together discussions of new products in a soap-like setting. Harold Macmillan's (actually rather wary) analysis that people had 'never had it so good' was taken at face value, and consumer outlay increased greatly across society, by one calculation growing 60\% in the period 1958-68. By that latter date the British were spending comparably less on food and other essentials, but $53 \%$ more on durable goods, and

\footnotetext{
23 C.W. Morle, 'Hi-Fi in America', Hi-Fi News, 5/1 (June 1960), 33; 'Readers' Hi-Fi Installations', $\mathrm{Hi}-\mathrm{Fi}$ News, 11/1 (June 1966), 75.

24 Basil Hyman and Steven Braggs, The G-Plan Revolution: A Celebration of British Popular Furniture of the 1950 and 1960 s (London, 2007), passim. That company's hi-fi furniture is seen in Hi-Fi News, 2/8 (January 1958), 400.

25 Paul Evans, The 196os Home (Oxford, 2010), 43.
} 
buying more of their expensive items like furniture and hi-fi on credit, to boot. ${ }^{26}$ Consumption, and an aspiration towards more of it, was part of growing prosperity, but also of the expansion of the middle class. Industrial workers were becoming fewer in number, but their wages rose $20 \%$ over the course of the 1950s; a million white collar jobs were added in the same decade. Traditional class- and occupation-based political allegiances weakened, ceding to new, more socially mobile kinds of consumer identity. ${ }^{27}$ Such trends continued through the 1960 .

Experience of modern domestic design was not limited to a static middle class. And however it looked in Architects'Journal or Ideal Home, neither was it commonly lived with total aesthetic rigor, or without ambivalence. As the $1960 \mathrm{~s}$ began, working and lower-middle class residents of modern housing developments routinely upset architects whose attempts to create light and space through provision of windows and open floorplans were disrupted by net curtains, extravagant pelmets, and room-dividing reproduction furniture. ${ }^{28}$ This wasn't just a class-based misconstrual of an unofficial stylistic code, and neither was 'middle-class' hi-fi a project entirely belonging to the modernist vanquishers of homely tradition. The distinctive forms and claims of design in the modern style and era, the design historian Kjetil Fallan has argued, can lead historians to overlook what was the enduring presence of the 'non'-modern. So it's important to record the reality of postwar British modernity as lived (and featured in Hi-Fi News) in the early 1960s, rather than idealised then or later: the super-modern, glass, wood, and butterflyroofed entertainment annexe adorned with a shelf full of porcelain dogs; the article on readers' set-ups that pictured one system in an elegant and lean wooden cabinet, another inside an ornate Queen Anne chest topped with a hand-carved Spanish galleon. ${ }^{29}$ As I will come to argue, it's only the acknowledgement of hi-fi's 'nonprogressive' other that can reveal its full domestic meaning. Situating an innovative

\footnotetext{
${ }^{26}$ This is in 1968 prices: in 1958 prices the figure was 60\%, illustrating the proportionate growth of expenditure allocated to durable goods from the late 1950s to the late 1960s. Economic Intelligence Unit, ‘Ten Years of Retailing', Retail Business, 121 (March 1968), 5, 8.

27 David Kynaston, Modernity Britain, 1957-62 (New York and London, 2013), 429-33; Avner Offer, 'British Manual Workers: From Producers to Consumers, c. 1950-2000', Contemporary British History, 22/4 (2008), 537-571.

${ }^{28}$ Judy Attfield, 'Inside Pram Town: A Case Study of Harlow House Interiors, 1951-61', A View from the Interior: Women and Design, ed. Judy Attfield and Pat Kirkham (new edn, London, 1995), 215-238. See also Judy Attfield, Bringing Modernity Home: Writings on Popular Design and Material Culture (Manchester, 2007). This wasn't just an assertion of 'old' taste versus the 'new': Angela Partington argues that modern-style impersonal functionalism represented a kind of regulation made on the part of 'male' bodies (manufacturers, the Council of Industrial Design) with the aim of policing domestic life. 'Clutter', 'trinkets', decorative knick-knacks, while abhorrent to modern designers, materialised interpersonal meanings and memories; people, often women, complicated the modern with their own enactments of tradition. Angela Partington, 'The Designer Housewife in the 1950s', A View From the Interior: Women and Design, ed. Judy Attfield and Pat Kirkham (new edn, London, 1995), 208-9. ${ }_{29}$ Kjetil Fallan, Design History: Understanding Theory and Method (London, 2010), 19. Anon., 'Hi-Fi House', Hi-Fi News, 6/4 (September 1961), 215; Anon., 'Readers' Hi-Fi Installations', Hi-Fi News, 9/4 (September 1964), 301.
} 
domestic technology within a British home that was - whether by class, ideology or taste - conflicted in its attitudes towards the modernity on display, suggests that other meanings might be equally murky (even if few of them are apparent from an analysis of hi-fi's written commentary alone).

Still, audio equipment claimed an increasingly visible place in the home through the 1960s. In West Germany, Hans Gugelot and Dieter Rams had in 1956 designed for Braun the SK4 Phonosuper, a machine that didn't attempt to conceal its purpose and workings: made to sit on rather than in a cabinet, the unit's clear plastic lid dramatically staged the turntable and tone arm that justified its presence. ${ }^{\circ 0}$ Braun's audio products were visually rather than sonically distinguished, and they made little impact on the UK market at the time. Yet their stylistic influence was powerful, and by the mid-1960s acrylic turntable lids were everywhere: hi-fi was achieving livingroom transparency. ${ }^{31}$ A 1965 Goldring advert featuring a clear-lidded turntable trumpeted its in-keeping with 'the modern trend towards shelf and table installations', one equally applying to tuners and amplifiers; the changeover to unconcealed separate units was quick enough that, by 1969, a Hi-Fi News writer could mourn the 'older and perhaps more "homely" method' of installing kit in a cabinet, with shelf-mounting 'now becoming the rule rather than the exception'. ${ }^{2}$ The divide had been articulated: on one side a generation for whom the 'homely' excluded technology, and on the other a group for whom the home could be an avowedly mediatised space.

Hi-fi did not stake a place in the home without modifying its accessibility, and a more fully consumerist positioning of audio technology supplanted the hand- and homemade. Hi-fi hobbyism - self-build projects, radio operation - receded in British hi-fi discourse through the early 1960s.33 Previously, equipment adverts had been

$3^{0}$ The plastic was also functional, since it minimised audible vibration while protecting the unit's workings and the record. Klemp, 'Dieter Rams', 345.

${ }^{31}$ However, a Hi-Fi News editorial commented on some 'wifely opposition' to this new visibility in hi-fi separates: Hi-Fi News, 9/12, (May 1965), 1085.

${ }^{2}$ Hi-Fi News, 9/10 (March 1965), 857; Eric Robjohns, 'Shelf or Cabinet', Hi-Fi News, 13/8 (February 1969), 181. That didn't mean that hi-fi had removed itself from the category of furniture, since, metal fascias apart, before the 1970s most separate units were housed in the same teak or walnut that was used for quality chairs, tables and sideboards. Plastic housing was largely reserved for cheaper equipment. 33 Keightley argues that, since its components required little special skill to link together, hi-fi's early hobbyist image was largely a marketing appeal to ideas of practical manliness. But until the latter-1960s, $\mathrm{Hi}-\mathrm{Fi}$ News frequently ran complex, months-long projects that enabled readers to build speakers and organs from scratch, and these required a degree of electronics knowledge; many enthusiasts called upon good woodworking skills to build housing for their units (having been a regular feature through to the mid-196os, Hi-Fi News' readers' installation photo spreads were all but done away with thereafter, since they had provided solutions to a storage problem gone by late-decade). Not only the range of abilities, but also the types of technical interaction that hi-fi users valued were wider than Keightley allows for. An important element of the UK hi-fi discourse was centred on the practice of radio listening (this an avowedly active alternative to what was often thought of as a passive and feminised pastime). For many years, A.H. Uden contributed diaries and articles tracking - to the day - weather conditions and resultant ability to pick up distant broadcasts. Uden reviewed tapes that readers had made of their radio reception, commenting approvingly on the clarity and lack of fading that, by investment, trial and 
laden with graphs and spec, but now a new, non-specialist market was targeted by different kinds of appeal: 'The man who knows what's inside says - you get more out of Telefunken' read one advert, its illustration showing a technician looking on at potential buyers rather gravely, twiddling a knob while he did the knowing on their behalf. ${ }^{34}$ Appeals to the hobbyist and the generalist were juxtaposed through the 1960s (and would remain so), but the level of knowledge and interest in hi-fi's inner workings that advertisers had once assumed quickly declined. A 1969 Wharfedale pitch attempted to capture this attitude: 'why get up to your eyes in statistics', it asked, 'when it's really up to your ears?'35

But increasingly it was up to the eyes. In 1960, Pye claimed to have 'today's bestlooking listening', and months later Truvox claimed of its tape recorders: 'THEY LOOK SO GOOD. THEY SOUND SO GOOD. THEY ARE SO GOOD'. ${ }^{36}$ Still a common perception was that British-made equipment was less than fully competitive in international markets, and this was sometimes attributed to a rather austere approach to styling, which contrasted with the metallic sleek of American firms like Fisher and Marantz. ${ }^{37}$ Nevertheless, by 1960 a number of firms had evolved recognisable aesthetic identities across their ranges, and this at a time when such brand uniformity was relatively unusual in product design. Quad's components all bore the nearly-blank fascia, flush rotary dials and sans serif font that they had and would for decades (and the company's famous and free-standing ESL electrostatic speaker was equally identifiable); Armstrong, pioneers in the integrated tuner/amplifier and separates market, cultivated a similarly muted identity. ${ }^{8}$ By the mid-196os, Ideal Home began to offer advice to readers on hi-fi that was often concerned with placement and look rather than sound, and that reflected a growing interest in newly visible equipment on the part of the design community as a whole: in 1966, the Council of Industrial Design included two Pye receivers styled by Britain's leading furniture designer, Robin Day, in its laudatory Design Index. As

error, readers had achieved. Keightley, 'Turn it Down', 151; P.A.J. Bachelor, 'A High Quality Stereo Mixer', Hi-Fi News, 6/2 (July 1961), 98-101; A.H. Uden, 'FM Diary', Hi-Fi News, 6/7 (December 1961), 443.

$34 \mathrm{Hi}$-Fi News, 5/4 (September 1960), 218.

$35 \mathrm{Hi}-\mathrm{Fi}$ News, 14/8 (August 1969), 942.

${ }^{36} \mathrm{Hi}$-Fi News, 5/4 (September 1960), 299; Hi-Fi News, 5/8 (January 1961), 539.

37 See J.D. Jones' letter to 'Our Readers Write', $\mathrm{Hi}$-Fi News, 10/2 (July 1965), 135; also 'Editorial', $\mathrm{Hi}-\mathrm{Fi}$ News, 10/9 (February 1966), 829.

${ }^{38}$ In comparison with Braun and the work of its designer team led by Dieter Rams, these designs were busy and even friendly, but the astonishingly inert presentation of material and function offered by that company - 'a rather gaunt type of styling', commented $\mathrm{Hi}$-Fi News in 1966 - was marked. Anon., 'IAFF '66', Hi-Fi News, 11/1 (June 1966), 41. 
much as its sonic capability, it was hi-fi's visual aestheticisation that was making it an attractive proposition in non-specialist markets. ${ }^{39}$

\section{Women as consumers}

If studies of hi-fi have not yet given a full picture of the audio-equipped, mid-century home, it's partly because - while gender has been a key concern - that technology has not been situated among the full range of activities, roles, experiences and aspirations dwelling there. When during the latter-1960s and early 70s women contributed articles or letters to Hi-Fi News, the trials of a husband's hobby were the subject. But it's significant that in Britain it was not always, pace Keightley, hi-fi's volume, visual presence or territorial claims that were in question: another major sticking point was audio's competition for household resources with other emerging domestic technologies, these allied with women's work rather than men's leisure. ${ }^{40}$ In 1970, Hi-Fi News published a piece by Mary Morgan that offered 'a wife's point of view' of the hi-fi hobby, and which smouldered with anger:

\footnotetext{
I am probably only one of many wives who, out of necessity rather than through their own choosing, have had to alter their way of life for the sake of this all-demanding, allconsuming hobby ... Possibly the greatest irony of all is that I am still without a washing machine, an electric cleaner, and carpets in all rooms but the lounge. And the only reason my husband so readily agreed to buying this carpet was because it would damp the acoustic resonance of the room. ${ }^{41}$
}

'Men's magazines' of the time, even those as different as the British Hi-Fi News or the American Playboy, habitually represented the world outside as the domain of work and the home as a place of repose. That separation, whether imagined or lived, was largely unavailable to women, whose journals were full of models who looked like the young Queen, wiping numberless plastic surfaces clean with endless disposable paper towels, putting a trifle in the fridge, sweeping up, making ice. Likewise women's experiences of home audio did not always mark the distinction, sometimes only a couple of movements removed, between employment and enjoyment. Claire

\footnotetext{
39 See Anon., 'The Sound of Music', Ideal Home, 90/5 (November 1964), 145-7, 149; Anon., 'Colour, Comfort and Co-Ordination', Ideal Home, 93/5 (May 1966), 69. For a detailed study of a later manufacturing and marketing process in which visual design and projected consumption practices are shown to precede questions of engineering, see Paul du Gay, Stuart Hall, Linda Janes, Hugh Mackay and Keith Negus, Doing Cultural Studies: The Story of the Sony Walkman (London, 1997).

${ }^{40}$ Certainly battle-of-the-sexes pieces in the terms that Keightley describes in a US context can be found in the British Hi-Fi News: see, for example, 5/12 (May 1961), 879; 6/1 (June 1961), 51.

${ }^{41}$ Mary Morgan, 'Hi-Fi Mania - a Wife's Point of View', Hi-Fi News, 15/4 (April 1970), 549. For another example see 'Our Readers Write', 11/5 (October 1966), 443.
} 
Langhamer's oral history of mid-century British women's leisure shows many then working as housewives recalling dedicated radio listening - with the pop and light music of Radio Luxembourg a favourite - because it accompanied and provided variation to their tasks..$^{2}$ This was true of single women as well, as G.C., a rugby- and music-loving 18-year old training in an Edinburgh accountant's office, recorded on several occasions in her 1950 s diaries. On Monday 1 August 1955, she declined a usual night in the coffee bar or at the Dominion cinema: 'I have stacks of washing to do and there is a one in a million Promenade Concert on tonight - Grieg's Piano Concerto in A minor, Schubert's Unfinished Symphony \& Overture to William Tell. At the moment', she wrote between suds and mangle, 'I am in the world of dreamland and music'. 43

Feminist historians have positioned the postwar culture of consumerism and interior decoration as a new kind of middle-class women's work, this coming into being following the departure of the servants and 'help' that had been fixtures into the 1930s. The new duties - design, ordering, maintenance - were not leisure, but labour, and labour towards something like an old patriarchal end; as Judy Wajcman argues, in recognising as much, feminist studies from the 1970s were wont to view consumer technologies as inherently exploitative of women. ${ }^{44}$ Yet, Angela Partington has written, new consumerist decision-making offered its own satisfactions, even if these were 'channelled, regulated and controlled' by the journalistic and commercial arbiters of good housekeeping. 45

Moreover, hi-fi manufacturers and discourses ascribed women an ambiguous domestic agency of their own. While the study of hi-fi at mid-century is a study of aspirational middle-class life - and as such will never reveal much in the way of thoroughgoing 'resistance' to unbalanced domestic power relationships, or consumer capitalism - it can pick up quiet indications of middle-class women's changing status in the home, as partners, consumers, listeners and critics. After all, hi-fi businesses did not simply elect to redesign their products and transform their market from a specialist to a general one: that process entailed a complex series of negotiations, abstract and concrete, between producers and consumers, offers and take-up. The challenge is to find a way of reading that move from concealing cabinets to visible

42 Claire Langhamer, Women's Leisure in England, 1920-196o (Manchester, 2000), 86. See also Smith, Spoken Word, 69ff.

43 Diary of GC, The Great Diary Project, Bishopsgate Institute Library, file GDP 1/1955.

44 Judy Wajcman, 'Reflections on Gender and Technology Studies: In What State is the Art?', Social Studies of Science, 30/3 (2000), 449-50.

45 Partington, 'The Designer Housewife in the 1950s', 208. Claire Langhamer's oral historical research with women working as housewives in postwar Britain confirms that domestic roles brought types of pleasure as well as obligation and drudgery. Langhamer, 'The Meanings of Home'. 
separates that might circumvent written hi-fi discourses in which women are either put-upon or passive.

It may be that the nature of domestic female agency is revealed by what the cabinets couldn't contain. In the 1950 s loudspeakers were often large, self-standing, and were articulated in a design language native to the front room: many corner speakers were plinth-like, and the Quad electrostatic unit was shaped like a firescreen. But their visibility, the space they demanded, evidently posed a political problem in a domestic territory traditionally (if not wholly) seen as a female, and it's here that visual materials tell us something the male-authored written discourse does not. From the mid-1950s, women's power of veto over hi-fi purchasing decisions was implicitly acknowledged, and fears assuaged, by a remarkably durable advertising trope, in which a woman - sometimes, as Freudian audiophiles might have noted, just a leg, seen from a child's eye view and metonymic of 'woman' - was positioned next to such a speaker in its domestic setting. If the women were elegant, they were hardly eroticised 'objects', and whatever the brand, the message was always the same: female co-consumers will judge this product neat, affordable, and compatible with their homes. ${ }^{46}$
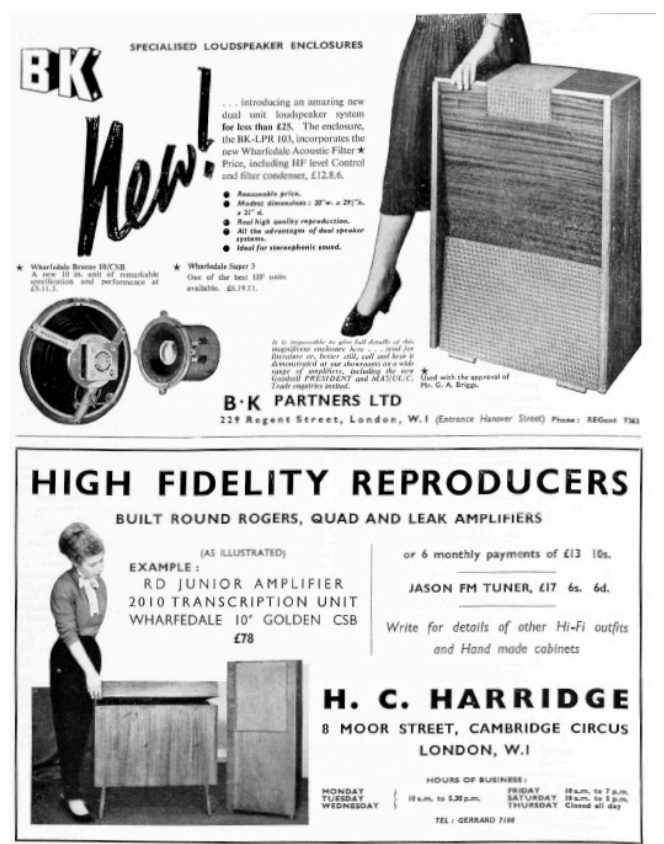

Figure 1. Adverts in Hi-Fi News 1/5 (October 1956), p. 186

Indeed, far more than the sense of manly superiority trumpeted by American written commentary and critiqued by later historians, advertisers in Britain

${ }^{46}$ As Thomas Everrett has shown, similar strategies were in use among radio manufacturers in 1920s America. Everrett, 'Ears Wide Shut', 69-70. 
attempted to sell their products as the agents of domestic consensus - which, in the 1950s, meant marital consensus. Firms at all levels of the market pictured happy couples at home with their new products, clasping each other in celebration of their consumer wisdom and (the two were related) their unimpeachable heteronormativity. Like other visual tropes, this one was imported into the hi-fi imaginary from a wider advertising discourse, and any number of similar couples stood in intimate but respectable proximity in furniture ads through the 1950 os and 605.47

These devoted pairs illustrated a particular domestic-historical situation. The period spanning the interwar years to the 1960 s represented the peak of long-lasting marriage in Britain (death kept it short before, divorce thereafter), and, as sociologists observed, in the decades following the war British men were becoming more 'home-centred'. Studies reported a new kind of companionate marriage that entailed greater domestic privacy across the classes, a greater social self-sufficiency within the family unit - with long-declining birth rates producing the 2-child nuclear family by the start of the postwar period - and increased uptake of female-identified activities, like home design, among men. '[T] he assumption that postwar domesticity and "traditional" gender roles were mutually reinforcing', Claire Langhamer writes, 'needs to be challenged'. 48

At the same time, and largely because they were spending comparatively less of their adult lives tending to children, women were forming an ever-greater part of the workforce not just in, but also outside the home, and the married among them especially: the proportion of those women working roughly doubled between the start of the 1950 and the mid-1970s, by which point it was around 50\%, with much of this growth occurring after 1960.49 Whatever the limitations of agency they continued to experience - the housekeeping allowances doled out weekly, the shopkeeper's enquiring whether husband had authorised a large purchase - women's share of economic productivity increased greatly through this period, and ideological notions of status and power within the family unit and the home shifted at the same time.

That mutation of roles can be read in the changing approaches that hi-fi businesses made to an imagined female consumer. The women of 1950 adverts showed a contentment derived from domestic order, not musical engagement, but by the end of the decade manufacturers and the specialist press would position and target women as listeners and buyers as much as obstacles to household purchasing.

\footnotetext{
47 See for example Hi-Fi News, 5/7 (December 1960), 512; Ideal Home, 73/4 (April/May 1956), 2.

48 Pat Thane, 'Population and the Family', A Companion to Contemporary Britain 1939-200o, ed. Paul Addison and Harriet Jones (London, 2005), 42-58; Langhamer, 'The Meanings of Home', 356.

49 David Coleman and John Salt, The British Population: Patterns, Trends, and Processes (Oxford, 1992), 141, 371.
} 
Old representations of female pleasure-in-order, and new ones of pleasure-in-audio, can be seen meeting in a Goodmans advert from 1964: here, a woman alone listens in front of her bookshelf speaker, this a technology newly arrived from the US, one more compact and fully integrated with regular furniture than speakers ever had been..$^{50}$ During the latter part of the decade, women were increasingly pictured as the sole users of stereo systems, and - while these images did little to overturn standard ideals of male-observed female beauty - they could now be seen taking the contemplatory poses that, as we have seen, had been reserved for men. Meanwhile, as part of a plainly deliberate editorial strategy, a spate of $\mathrm{Hi}$-Fi News covers in 1968-9 pictured young women listening at home, alone or as part of a couple, and often to pop records - as I will explore later, newly constructed associations of gender and genre were significant in home audio's growing adoption.

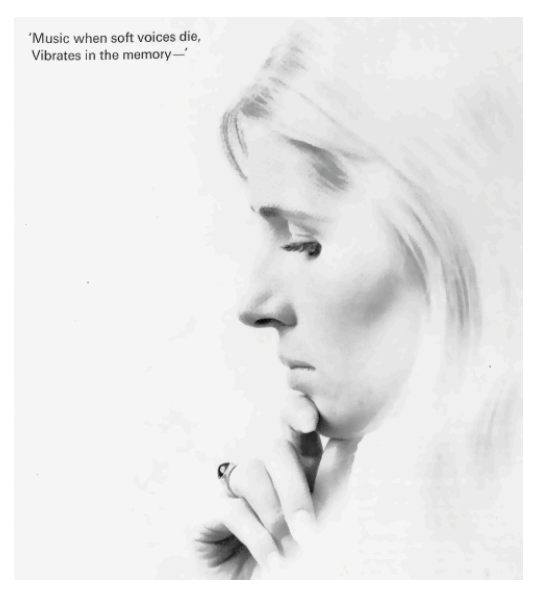

Figure 2. Detail of SME tone arm advert, Hi-Fi News 13/8 (February 1969), p. 135

\section{Touch}

Although women were increasingly framed as attentive hi-fi users, their listening was still often portrayed as qualitatively different from men's. From the 1950 s and well into the 1970s, when women were pictured listening in the hi-fi literature they were only sometimes sitting upright in chairs, like that male occupant of the 'sweet spot': to hear music, women usually sprawled, often on the carpet but sometimes on the settee. This was a female reverie to match the male, but one that suggested a different kind of sensual engagement with the immediate environment. If supposedly rational

$5^{\circ} \mathrm{Hi}$-Fi News, 9/4 (September 1964), 284. Relatively unusually for a hi-fi firm, Wharfedale would advertise their version in the female-targeted Ideal Home, 93/1 (January 1966), 13. 
man's attention was focused on a single point, then supposedly sensual woman was submerged in a dreamy kind of multi-sensory experience.
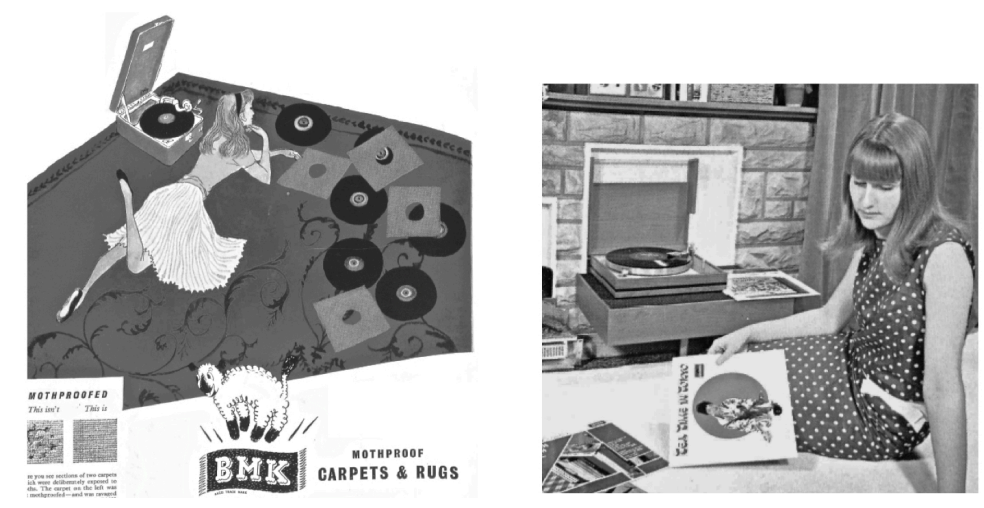

Figure 3. Back cover detail Ideal Home 69/2 (February 1954), and front cover detail of $\mathrm{Hi}$-Fi News (November 1967).

The critique of gendered representation here hardly needs to be made. What does need to be elaborated is the historical meaning of this figure in the domestic imaginary, because, once again, it wasn't an invention of the hi-fi press: the image of the woman on the floor, often listening to music but sometimes reading or just lolling, was found across domestic advertising. And it was an entirely modern thing to find relaxation and sensual abandon at that level. What would have been idle, louche or unladylike a generation earlier (and, perhaps, a class apart) was now, in an age of imagined domestic leisure, a pose to aspire to; what would have been cold, dirty or rough before the invention of central heating, vacuum cleaners and affordable, synthetic, wall-to-wall carpets, was now signalled as warm and clean by interested companies. Children, too, could sometimes be found pictured in this pose. But not men. The floor-sprawl signalled a tactile contact with consumable modernity just as the audio indicated another kind of sensual, bought contemporaneity. Yet it was allied to familiar gender expectations: for as long as consumerist discourses had existed, women had been associated - willingly or not - with domestic cleanliness. ${ }^{51}$ The sensual abandon to music and carpet helped describe the comforts of the ideal modern home, yet, once again, it also set pleasure in relation to domestic work and responsibility.

${ }^{51}$ Phyllis Palmer has argued that household dirt, discursively framed and tying women in a system of obligations, was not only a neutral, natural phenomenon, but a structurer of gender and, in the American context she investigates, 'race relations'. Phyllis Palmer, Domesticity and Dirt: Housewives and Domestic Servants in the United States, 1920-1945 (Philadelphia, 1990). 
Modes of tactile interaction with audio technology were developing beyond these gendered specifics, however. Happy couples, and order-policing wives, tended to disappear from adverts as the things they had vouched for became less of a concern, as audio systems were accepted into homes on their own visual terms and by a broader range of consumer; indeed, humans of any kind were increasingly extraneous to promotional pictures that, like consumer gazes, were now focused on the materiality of these uncovered machines. Incidentally marking that transition from hobbyism to consumerism, $\mathrm{Hi}$-Fi News' regular commentator, John Berridge, complained in 1960 about the complexity and abundance of knobs and dials on contemporary hi-fi equipment, especially American: he didn't want to fiddle with minutiae or run tests, but to listen to music. Returning to the interface between user and unit some months later, Berridge launched a request for manufacturers to make more use of the push button, the 'beautiful simplicity' of which gave the pushing action - and the click into place - its own tiny pleasure. $5^{2}$ These features gained currency with the growing use of plastics in domestic product design. In his study of plastics in 1950 s and 6os British domestic settings and discourses, the design historian Tom Fisher shows the new synthetic materials being systematically described as 'modern' and 'gay', and positioned against the drabness of the immediate postwar years. The tactility, shine and practicality of plastics heralded a new way of living; they were intriguing in their shapability, softness, warmth, colour; they invited a new kind of touch and micro-experience of home life. 53 The polystyrene Ultra transistor radio that won a 1961 Council of Industrial Design award suggested as much in its promotional photo, and in higher-fidelity contexts, too - most notably Braun in Germany, clearly an influence on Ultra's own design - much attention was being paid to the interface, and the inviting, finger-shaped concave of the push button. 54

\footnotetext{
$5^{2}$ John Berridge, 'Frankly Speaking', Hi-Fi News, 5/4 (September 1960), 275, and 6/8, (January 1962), 551.

53 Tom Fisher, 'A World of Colour and Bright Shining Surfaces: Experiences of Plastics after the Second World War', Journal of Design History, 26/3 (2013), 288-89. See also Fisher's 'What We Touch, Touches Us: Materials, Affects, and Affordances', Design Issues, 20/4 (2004), 20-31. 54 Dieter Rams, Weniger, aber besser / Less but better (Berlin, 1995), 38. For a contemporary discussion of trends in plastics' use, see Anon., 'Synthetics Win Status', Ideal Home, 83/9 (September 1961), 74-77, 79.
} 


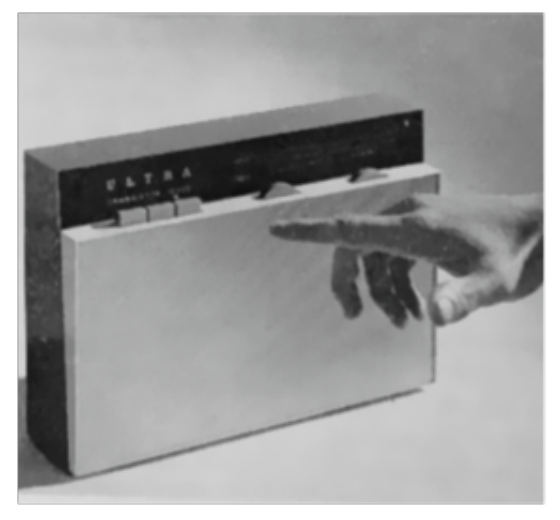

Figure 4. Ultra transistor radio, Ideal Home 83/6 (June 1961), 84.

The reviewer of the Bang \& Olufsen Beomaster 1000 who, in 1966, praised the unit's styling - including its 'quite aristocratic knobs' - described and responded to what was a new manufacturer attention to tactile interaction. ${ }^{55}$ This development was not limited to hi-fi, but was seen across the field of consumer engineering of which hi-fi was a part. Increasingly, controls and interfaces on amplifiers, washing machines and even car dashboards resembled each other, and 'brown' and 'white' goods began to converge in meaning and domestic ubiquity. In the early 1970 , interfaces resembling those of contemporary mixing desks and synthesisers were introduced: 'IT'S TOTALLY DIFFERENT - in sight, touch and sound!', claimed a 1972 advert for a Metrosound amplifier that replaced dials with faders, whether in recognition of a new popular awareness of the recording studio's visual language, or of a desire for latestage participation in the production process..$^{6}$ Later in that decade, hi-fi interfaces would mimic the controls and indicators of an aeroplane's cockpit.

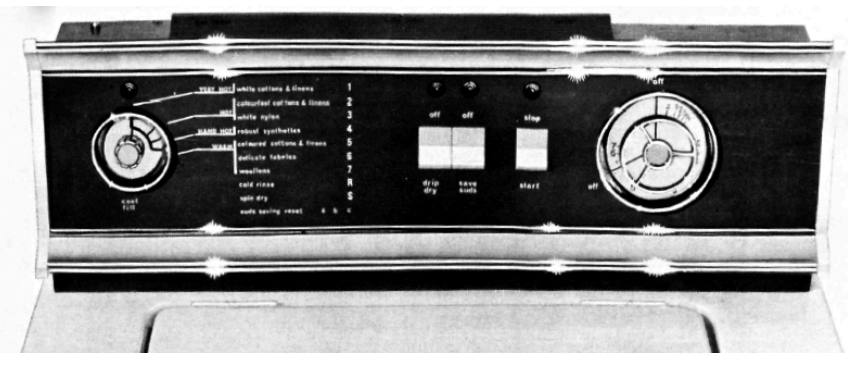

Figure 5. Detail of Parnall spin washer advert, Ideal Home 93/5 (May 1966), 120.

Studies of hi-fi tend to imagine it in isolation from the rest of the household, but it was only one of several different domestic technologies then converging in appearance, feel, presence and meaning; as Mary Morgan's article showed, it was

55 A.W. Wayne, 'Beomaster 1000', Hi-Fi News, 10/9 (February 1966), 867.

${ }^{5} \mathrm{Hi}$-Fi News, 17/2 (February 1972), 216. 
part of a struggle for resources in the modernisation of home utilities and comforts. But just as important, and just as neglected, is the task of setting hi-fi in relation to its audio 'other' - the cheaper, non-audiophile record players, tape machines and radios that not only outnumbered and outnoised high-end equipment, but did so on behalf of different constituencies. That kind of domestic audio was far more common than hi-fi, and, as Morgan had gone on to write, the two could be ideologically and even technologically incompatible:

\begin{abstract}
I had brought with me to our mutual home quite a selection of records collected over several years ... Little did I realise at the time, but three and a half years later my treasured record collection would be neglected, unused and stored carelessly in some dusty cupboard ... My records cannot be played, since they would damage the stylus having once used an inferior set-up. And since we only have one stylus, I therefore never hear them. 57
\end{abstract}

Morgan's piece tells us about masculine authority. But - continuing the search for lived experience and agency rather than familiar critique - it also invites us to think about how, and using what, she had listened to her records before marrying. Rewinding to the start of the 1960 s and taking another pass through the decade will add another dimension to the study of a growing market for audio equipment, and show something of the musical lives of those groups largely absent from earlier hi-fi culture.

\title{
Transistors and mid-fi
}

The greatest transformation of domestic life in the postwar era - and one abetted by the same transistors that would power radio and later hi-fi products - surely followed the introduction of television. In Britain, the hi-fi press kept an eye on TV's development - waxing technical or moralistic, mood depending - but uptake of the new device was far wider, and far less dependent on class or gender, than it was for equally pricey audio equipment. BBC research found that 'well over' half the sets in use in mid-1952 were in working class homes: a budget set cost $£ 50$, while the average weekly wage sat in the region of $£ 7$, but hire purchase was an enabler, and, much more than high-end audio, television ownership was a sign of status and modernity seen as worth shelling out for..$^{8}$ Between 1954 and 1964, the number of

\footnotetext{
57 Morgan, 'Hi-Fi Mania', 549.

${ }^{8}$ Su Holmes, Entertaining Television: The BBC and Popular Television Culture in the 1950s (Manchester, 2008), 27. Michael Young and Peter Willmott's classic 1957 study of life in Bethnal Green and 'Greenleigh' (Debden), a newly developed area in Essex, suggests the spread of television among
} 
household TV licenses issued rose from 3 million to almost 13 million, the latter 'effectively a national audience', as the television historian Rob Turnock comments. 59

Keir Keightley argues that, as much as hi-fi was coded masculine, television could be coded feminine, and the new medium was criticised - by a certain kind of commentator - as fatuous, too obviously made to a family pattern. Programmers of the 1950 s were aware that a show's success could be dependent on it being authorised by a wife or mother to enter into daily routine. ${ }^{60}$ But however the roles and rhythms of women, children and men's lives butted up against each other, and however fraught music's treatment on the new medium could often be, still - especially in pop form - TV music was central in developing new affective, gestural and intellectual ways of being in a newly visible wide world. That's another story. But if nothing else, it's important to note here the front-room reach that pop music-based programmes had. The weekly 6-5 Special - 'quite intolerably noisy', as one supposedly representative older viewer reported to the $\mathrm{BBC}$ - was watched by 5 million in 1958; Top of the Pops - 'a loathsome session of horrible cacophonous noises' - by around 17 million in the mid- and late-1960s. ${ }^{61}$ There's little point in imagining hi-fi audio in the home without listening to the racket from the next room, fuzzy, rattling and cramped in sound, but immense in significance.

Those ratings were achieved despite pop's central, teenage market containing fewer TV viewers than other age groups, as the sociologist-cum-market researcher Mark Abrams reported in 1959. Instead, this newly identified, economically empowered group was out and about, spending - in Abrams' perhaps optimistic estimation $-£ 17$ million per week, largely on leisure, and in the process accounting for $44.1 \%$ of the market for records and record players. ${ }^{62}$ Manufacturers knew about the money, and they knew about the mobility; by the early 1960 s a huge market existed for compact record players (with Dansette the best-known brand), reel-to-reel

working class communities: whatever the limits of their methodology, the sociologists reported that, despite its expense, television was in $65 \%$ of Greenleigh households by 1955 . The lack of amenities in the new development, they wrote, meant that families increasingly stayed in at night, gathering around the TV as a family unit. Family and Kinship in East London (London, 1957), 143.

59 Rob Turnock, Television and Consumer Culture: Britain and the Transformation of Modernity (London, 2007), 6.

${ }^{60}$ Keightley, 'Turn it Down', 150; Holmes, Entertaining Television, 34.

${ }^{61}$ Figures from 'Chart of TV Audiences Sat. 27 ${ }^{\text {th }}$ December 1958', BBC Written Archive Caversham, file T12/23/7; Paul Fryer, “Everybody's on Top of the Pops": Popular Music on British Television 19601985', Popular Music and Society, 21/3 (1997), 156. Viewer comments from BBC Audience Research Report, 'Six-Five Special, Saturday $16^{\text {th }}$ February 1957', BBC Written Archive Caversham, file T12/360/5; BBC Audience Research Report, “Top of the Pops, Wednesday, 12 August 1964', BBC Written Archive Caversham, file R9/7/70.

62 Abrams found that the earnings of Britain's 4.2 million 15-25 year-olds - his 'teenager' was defined broadly - had grown $50 \%$ from pre-war levels, averaging around $£ 8$ per week gross for males and $£ 6$ for females, but that their discretionary spending had probably doubled from that time. Historians have questioned whether Abrams' figures were not exaggerated, while allowing the shape of the dynamic he described to stand. Mark Abrams, The Teenage Consumer (London, 1959), passim. Pay disparity, Abrams wrote (p. 14), meant that 'at least 67 per cent of all teenage spending is in male hands'. 
tape machines (and after 1963, compact cassette players), and the new transistor radios - 22 million of which were in use by 1964, with retailers linking sales to pirate radio and Britain's first continual pop service. ${ }^{63}$ The relative portability of budget equipment attested to a culture of sociality and resource-pooling, and to a desire for territory, privacy or freedom. A 1961 Minivox tape recorder advert invited buyers to 'tape the top ten and play them at the party!' - as in hi-fi circles, home-taping was a popular practice - and promised "'pops" at a picnic or "blues" at the barbecue!'64 In Edinburgh, G.C. wrote in her diary entry for Sunday 6 January, 1957:

E. brought his girl friend S. back for tea. Very attractive Miss for only sixteen \& a damned sight more grown up than I was at her age. We had quite a pleasant afternoon. She had brought her gramophone with her \& they pounded out Rock \& Roll for hours until R. put Capriccio Espagnol on. It wasn't at all well received by either of them \& E. appeared to have gone to sleep. 65

Portable equipment could bring friends and families into musical proximity, and into conflict. The multiplying of sound sources, and of musical desires, inevitably led to domestic struggles over their control. But portability could also individualise, and the same was true of headphone listening, which in Britain began in earnest around the mid-196os: though the presence, sound quality and exclusion of outside noise they offered was attractive to hi-fi listeners, it was their privatisation of listening that was most remarked upon. Perhaps this wasn't coincidental, given what we will see to be the remarkable boom in pop record sales at the time. A February $1965 \mathrm{Hi}$-Fi News feature was illustrated with a photo of a small boy sat on the floor, A Hard Day's Night on the portable record player and headphones in place; his mother sits nearby, sewing while listening to the radio, as oblivious to the boy's chosen listening as he was to hers. ${ }^{66}$

Styling and touch were, if anything, more important to this market. The bold visibility of portable units contrasted with hi-fi still emerging from its smooth-planed Scandinavian cabinets, the mod angularity and bright colours common in Dansette

\footnotetext{
${ }^{63}$ Hire purchased helped this market as it did others. Record Retailer reported that, in March 1962, $27.8 \%$ of radios, $49 \%$ of radiograms and $48.1 \%$ of tape recorders had been bought on HP, and very similar figures had been recorded a year earlier. Record Retailer and Music Industry News, June 21 1962, 22. On Dansettes and transistors, see David Attwood, Sound Design: Classic Audio \& Hi-Fi Design (London, 2002), 22, 12. On transistor sales, see Economic Intelligence Unit, 'Special Report No. 3: Transistor Radios', Retail Business 107 (January 1967), 39.

64 Melody Maker, 11 February 1961, 11.

65 Diary of G.C., The Great Diary Project, Bishopsgate Institute Library, file GDP 1/1957.

66 T.D. Towers, 'Headphones and High Fidelity: Why Personal Listening is Blossoming', Hi-Fi News, 9/9 (February 1965), 781. On earlier headphone listening see Sterne, The Audible Past, and Everrett, 'Ears Wide Shut', passim.
} 
culture described instead as 'Italian'. ${ }^{67}$ These players were made of wood and metal, but also (washable) pigskin, vinyl and plastic: soft-padded and pleasingly artificial, they felt to the touch how everything that was modern about the house did. That somewhat unreal quality certainly applied to the dull, small sound of the average Dansette or pocket radio, although, as Sterne and others have noted, every period has its idea of fidelity and power (G.C. could hear a weak portable player as 'pounding' out rock and roll because of the style's qualities relative to the Capriccio espagnol). But pop culture was marked by a new appreciation of the synthetic, just as music increasingly identified with its recording, and with those who recorded it. ${ }^{68}$
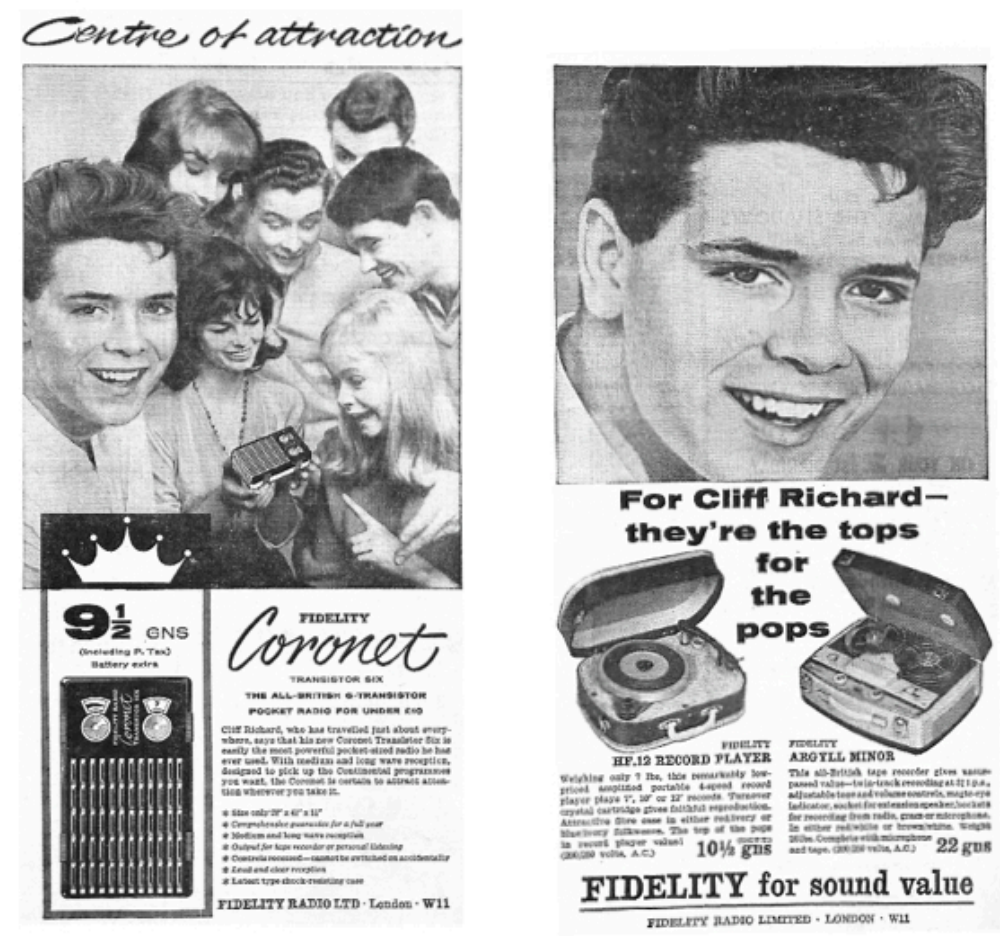

Figure 6. Adverts in Melody Maker, 24 June 1961, 5; Melody Maker, 14 October 1961, supplement i.

The divide between high and low fidelity equipment, and their markets, began to be bridged. In the specialist, musical and domestic press across the 1960s, introductory articles reassured readers that access to quality sound was possible, the entry level set between $£ 70$ and $£ 100$ at each point in the decade. ${ }^{69}$ And what was a historical British middle-class ambivalence towards electrical goods, much in

\footnotetext{
${ }^{67}$ Alfred Sorkin, 'Record Players “Still Holding Up”, Melody Maker, 4 February 1961, 15.

${ }^{68}$ Many microphone amplifiers with reverb units were advertised around 1962, the idea of the studio product beginning to envelop and transform the normative 'live' musical experience.

69 Tony Brown, 'Hi-Fi Needn't Cost You a Fortune', Melody Maker, April 21 1962, supplement, iv; William Chislett, 'The Sound of Hi-Fi', Ideal Home, 92/3 (September 1965), 21-2; S.F. Branham, 'Come and Join Us', Hi-Fi News, 15/3 (March 1970), 393, 395.
} 
evidence (or rather absence) in the domestic magazines of the mid-1950s, began to recede as more and more articles were devoted to audio and television equipment, if only gradually. ${ }^{70}$

Yet while those articles sometimes featured high-end equipment by companies like Quad, even as audio caught on, the middle-class, middle-brow market that was Ideal Home's readership was more often offered the middle-fi of brands like Pye and Bush. ${ }^{11}$ The strong growth seen in the audio equipment industry was not driven by audiophile manufacturers. In one of many comments that reflected a lack of faith in British audio manufacturing - and what was a collective loss of confidence in British industry as a whole - Hi-Fi News' John Berridge wrote in 1964 that British equipment was not faring well in the USA because of its adherence to high prices and specialist separates: it was the combination system, beginning with combined amplifiers and tuners and moving towards the integrated music centres prominent from the 1970s, that was motivating the growth and popularisation of better quality audio in the home. ${ }^{72}$ This was an increasingly international field. Middle and entrylevel markets especially were coming to be seen as the province of Japanese manufacturers like Sony, which had developed a reputation for providing technical innovation at low prices (and since the start of the 1960 s had prompted worried questions in Parliament because of it). 73

Nevertheless, the widening of the market continued, attracting more and more mid-market manufacturers and retailers. By 1970 a $\mathrm{Hi}-\mathrm{Fi} \mathrm{News}$ editorial was hailing the fact that 'high quality domestic music reproduction is achieving a break-through to a larger public', but wary of the fact that mass marketing and discount stores that were part and parcel of that trend would drive specialists from the market. ${ }^{74}$ This was a common complaint after the 1964 abolition of resale price maintenance - the longestablished manufacturers' price-fixing charter - and was made too by record (and furniture) retailers. These fears would be realised in the 1970s, when superstore chains would come to dominate those markets.

\footnotetext{
$7^{\circ}$ On that ambivalence, see Peter Scott, 'Mr. Drage, Mr. Everyman, and the Creation of Mass Market for Domestic Furniture in Interwar Britain', Economic History Review, 62/4 (2009), 826; and Roy Norris, 'Electronics for Home Entertainment', Ideal Home 70/6 (December 1954), 78-9.

${ }^{71}$ Anon., 'Home Entertainment', Ideal Home, 74/10 (November 1956), 189-204; Roy Norris, 'Progress Report: Television, Record-players, Radio', Ideal Home 74/10 (November 1956), 160, 163, 165.

${ }^{72}$ John Berridge, 'American Letter'. Hi-Fi News, 9/5 (October 1964), 431.

73 Anon., 'Questions Asked and Answered in Parliament', Journal of the Board of Trade, August 4 1961, 255 .

74 Anon., untitled, Hi-Fi News, 15/3 (March 1970), 351. See also: Economic Intelligence Unit, 'Ten Years of Retail', 18, 1, 13; Anon., 'Resale Price Maintenance - What the Associations Say', Record Retailer and Music Industry News, February 27 1964, 13; R. H. Fisher, 'Nothing for Nothing', Hi-Fi News, 9/10 (March 1965), 871. The magazine's own fortunes represented the boom, though. From the start of the 1960 s Hi-Fi News' circulation figures increased by around 50\% every five years, from a monthly average of 20,675 in September 1961 to 39, 398 in March 1970. But that rate of growth doubled in the first half of the 1970 , the magazine claiming 58,692 monthly sales by January 1976 .
} 


\section{Pure music}

The growing uptake of home audio was not solely the doing of the specialists, and nor was it entirely owed to a public awakening to the possibility of improved fidelity in the abstract (or even in its new material, usable form). Perhaps the central driver of this market expansion in hardware was, instead, the new cultural and material ubiquity of pop music, of the records and tapes the equipment served. In the space of a few years in the 1960s, music, kit and market would develop in trio from a lo-fi culture into one that accommodated mid- and even hi-fi aspirations.

Articles in the popular music press around the turn of the 1960s explicitly positioned the pop fan's standard, low-budget equipment against hi-fi. That, as Melody Maker had it, was 'a minority cult for the wealthy', for a bunch of boffins 'in search of an ideal' and 'more preoccupied with pure sound than pure music'. ${ }^{75}$ What it meant to be a pure music fan was shown in one of the quasi-sociological reports that the same paper published mid-decade: while many bought a record only here or there, a significant number of pop and beat fans - at their purchasing peak in their early twenties - bought records, usually singles, continuously.

\footnotetext{
I buy a couple of singles a week, sometimes three, including all the ones by the Beatles, Rolling Stones and Cliff Richard. I don't usually go for girl signers but I get Cilla Black's new releases. Never buy records by Adam Faith or Marty Wilde. I can't usually afford to buy LPs. So I ask for them as birthday presents. My father bought my record player for Christmas - Wendy Draper, 17-year old $£ 7$-a-week glass sorter, of Coventry.
}

I buy about three LP's a year, and spend between nothing and $15 \mathrm{~s}$ a week on records mostly singles. I don't consider myself a heavy record buyer. One of my friends regularly spends £2 a week or more - Mavis Pain, 18-year old office worker, Leyton, London. ${ }^{76}$

As the hi-fi press frequently complained, 45rpm pop singles, cheaply recorded and often pressed on cheap vinyl before being played on cheap record players, evinced little concern for purist audio standards. And it was singles sales that drove the dramatic expansion in record manufacturing in the early decade. Increasingly, though, those few annual purchases of LPs would grow and help transform pop music

\footnotetext{
75 Tony Brown, 'Stereo for $£ 75$ - We’ve Done It', Melody Maker, April 21 1962, supplement, ii. The same sentiments are expressed in Roy Norris, 'Record Players: Quality Up, Prices Down', Melody Maker, October 4 1958, supplement, viii.

${ }^{76}$ Ray Coleman, Bob Dawbarn and Chris Roberts, 'Fanmanship - Read All About Yourself', Melody Maker, August 15 1964, 8-9.
} 
into a culture whose basic unit could be either single or album - the latter hitherto classical or jazz, and the hi-fi format par excellence. From Christmas 1963, when business was centred on the release of With The Beatles, the trade papers were beside themselves with excitement over a record sales boom; by 1966, only around one third of LPs sold in Britain were described as classical, the balance covering a broad spectrum of pop and light music (with a small amount - around $5 \%$ in the case of EMI's output - given over to jazz, folk, spoken word and educational records). 77

\begin{tabular}{c|c|c|c|c|}
\multicolumn{1}{c}{ Number of records pressed in thousands } \\
\cline { 2 - 5 } \multicolumn{1}{l|}{} & 78 r.p.m. & 45 r.p.m. & 33 1/3 r.p.m. & Total \\
\hline 1955 & 46,347 & 4,587 & 8,989 & 59,922 \\
1956 & 47,508 & 6,903 & 12,116 & 66,527 \\
1957 & 51,359 & 13,161 & 13,765 & 78,285 \\
1958 & 28,314 & 27,521 & 15,620 & 71,455 \\
1959 & 8,126 & 43,230 & 15,404 & 66,761 \\
1960 & 3,803 & 51,811 & 17,057 & 72,670 \\
1961 & 2,181 & 54,757 & 19,388 & 76,327 \\
1962 & 1,944 & 55,239 & 20,361 & 77,544 \\
1963 & 1,846 & 61,342 & 22,267 & 85,454 \\
1964 & 587 & 72,841 & 27,829 & 101,257 \\
\hline
\end{tabular}

Table 1. Source: 'The Complete Figures'. Record Retailer and Music Industry News, July 8 1965, 16.78

Growing record collections helped grow equipment sales. The Economic Intelligence Unit identified Beatlemania as the force behind 1964's peak record player sales (576,000 units that year); the Unit calculated that nearly half a million record players were still being sold in Britain during $1967,70 \%$ of them to first-time buyers, and with a 'distinct ownership bias' towards 16-24 year-olds hailing from the professional middle classes. Most of the equipment sold was mid-market $-75 \%$ of 1967's record players had sold for less than $£ 35$ - with the average spend being £24 (which bought a product like Philips' Audioplan model; cheap portables could be had

\footnotetext{
77 Anon., “Nothing Like this has Happened Before”, Record Retailer and Music Industry News, December 5 1963, 16; Economic Intelligence Unit, 'Special Report No. 2: Gramophone Records', 25, 26. It seems that 'adult pop' (Sinatra et al) had long accounted for even more of the US LP market. See Keir Keightley, 'Long Play: Adult-Oriented Pop and the Temporal Logics of the Post-War Sound Recoding Industry in the USA', Media, Culture \& Society, 26/3 (2004), 388, note 3.

${ }^{78}$ Figures - including minor discrepancies in the totals column - are reproduced here as originally printed. As retailers frequently complained, these figures, calculated by the Board of Trade, showed records pressed by manufacturers, not sold at the tills, but the trend was clear. Anon., 'Many Dealers Say Sales Figures Not Accurate', Record Retailer and Music Industry News, March 24 1966, 9.
} 
for not much more than £10). Some $28 \%$ of homes had a record player by 1967 , up from around $20 \%$ in 1960.79

The growing youth and pop demographic made inroads into bona fide hi-fi circles too. Musical content in $\mathrm{Hi}-\mathrm{Fi}$ News had often been limited. In the latter-1950s, reviews (and adverts) tended to cover light music orchestras, light classical and opera, military bands and parts of the core classical repertoire. By the mid-1960s things had got more serious, and - with a full roster of canonical repertoire by then easily available on LP - things were more fully geared towards classical music. The emphasis on what was sometimes thought 'heavy' music brought some complaint, but a restatement of longstanding policy by the magazine's editors in May 1966 clarified that, being a hi-fi magazine, only recordings of a high technical standard could be reviewed, and that that ruled out a lot of popular musics and music recorded for budget labels: 'the only type of music that is excluded', the editors wrote, was 'the ocean of ephemeral "pop" and dance music which lies between genuine jazz on the one hand and good light music on the other'. ${ }^{80}$

But a seachange was upon them. In summer and autumn 1966 a couple of readers countered that, rough-and-ready as it sounded, they liked the Rolling Stones in hi-fi, even if their peers didn't: 'if I mention anything about hi-fi and record care to my friends (auto-changer radiogram types)', one wrote, mobilising old technological snobbery in a new taste context, 'they think I am being unnecessarily fussy, and genuine (?) hi-fi enthusiasts believe that anything that cannot be listed as classical is complete rubbish. ${ }^{81}$ Blimpish magazine commentary on the artificiality and transience of modern pop continued - 'will anyone even have heard of the Beatles, etc., a generation from now?', an editorial asked in April 1967 - but it was that Stones fan who was soon identified as the future, and representative of a market the hi-fi industry would want to capture. ${ }^{82}$

So the magazine increasingly published letters from those asking for more pop, and - a notable gambit of the period - commissioned legitimating articles in which groups like the Beatles and Beach Boys were hailed for the musical complexity of their work. ${ }^{83}$ By 1968 a much greater range of jazz records was being reviewed, and as advertisers spent more on promoting pop records and tapes, so pop and rock reviews

\footnotetext{
79 The non-budget 'record player' itself was a sign of industry change: hi-fi motor units, pickup arms and cartridges had been (and would continue to be) offered separately and combined by the discerning customer, while record players - technically suboptimal, but sold as a package and ready to play - had been scorned by audio buffs. This was now changing, to an extent.

80 Anon., no title, Hi-Fi News, 10/12 (May 1966), 1187.

81 'Our Readers Write', Hi-Fi News, 11/4 (September 1966), 333.

82 'Our Readers Write', Hi-Fi News, 11/11 (April 1967), 1173.

83 T.R. Edwards, 'You Don't Know What You're Missing: A Fresh Angle on the "Pop” Controversy', $\mathrm{Hi}-\mathrm{Fi}$ News, 12/2 (July 1967), 169, 171, 183.
} 
increased, until, by 1969, the magazine offered a genuinely eclectic mix of music: Don Ellis, Bob Dylan, Delius, Otis Redding, Three Dog Night, Messiaen, Archie Shepp and Schoenberg rubbed shoulders across a couple of issues, with letters page dissent either absent or suppressed in the name of market realpolitik. ${ }^{84}$

The maleness of those artists was not coincidental: what was being accepted into the hi-fi fold was not that 'ephemeral pop' which, as a great many commentators have noted, was often gendered as female, but the newly arrived - and authentically masculine - rock, jazz and $\mathrm{R} \& \mathrm{~B}$. That distinction was made again and again in articles, often with a sign-of-the-times triangulator in the shape of the formerly staid BBC, which was by now playing continuous pop on (low-quality, AM mono) Radio $1 .{ }^{85}$ The best statement of the new market reality was made by a reader, John G.C. Stepney, of Edinburgh:

In the last few years a new type of 'pop' music has developed, namely 'rock' or 'underground music', practically all of which is issued on LP (stereo) records, the sales of which exceed those of singles. In America, where the system of broadcasting is somewhat different, this distinction has been recognised and there are multitudes of 'Top Forty' stations broadcasting on AM, while the 'Rock' stations go out on FM, in stereo. It is about time the BBC acknowledged the existence of 'rock' as something other than the interest of what they seem to think is a minority. ${ }^{86}$

Here was a hi-fi enthusiast for the 1970s.

\section{Conclusions}

Domestic audio cultures had changed irrevocably - their participants, their social associations, their sounds and even their manufacturing materials. Over twenty years, Britons' earning and spending power, not least that of women and young adults, had grown in tandem with a culture and ideology of consumerism, and with the design and marketing strategies that both sought and shaped those new markets. Entertainment technologies and media had been accepted into the home across classand age-groups, although a youth market, culturally and financially empowered, was especially forceful in driving the expansion of entry-, mid- and eventually high-level audio in the home. An increasingly lucrative industry was subject to increasingly aggressive competition, particularly as the British market opened up to international

\footnotetext{
${ }^{84}$ A 1970 editorial noted that only 2\% of readers' letters were published. Anon., no title, Hi-Fi News, 15/1 (January 1970), 51.

85 Adrian Hope, 'Pop: The Proverbial Curate's Egg', Hi-Fi News, 14/9 (September 1969), 1031, 33.

86 ‘Our Readers Write', Hi-Fi News, 15/5 (May 1970), 699.
} 
manufacturers like those Asian companies which, famously, came to produce innovative technology at prices that were beyond the lower reach of smaller British firms. This is a picture of change that is only fully visible when the cultural-historical emphasis on representation is reinforced by a different kind of sourcework.

But there was also an amount of continuity in the ways that audiophile tastes and identities remained sectioned off from those of the 'masses' (even if popular music was now accessible to those on both sides of the imagined divide). Continuous also were gendered aspects of the discourse - even if female consumers were now more often courted and heard from - including the visual tropes that did so much signifying work. Here, that cultural-historical study of representation remains valuable: the cover of February 1974's Hi-Fi News featured a woman in timehonoured listening pose, sat on the floor and gazing at album covers, a 'feminine' way of being fixed once more on the page and in the imagination. Other things had moved along though, and a discount store's advert in January 1972 had a model laid out, naked, smiling, a contrast indeed with the twin-setted wives of the mid-1950s. This was to be a newly permissive era, one in which controls over both retail price and the stark mainstream sexualisation of women had been removed. The advert's seedy slogan: 'we take off more'. 87

${ }^{87} \mathrm{Hi}$-Fi News, 19/2 (February 1974), cover; Hi-Fi News, 17/1 (January 1972), 162-3. 